\section{Ankara Üniversitesi Eğitim Bilimleri Fakültesi Özel Eğitim Dergisi}

2022, 23(2), 345-364
ARAŞTIRMA

Gönderim Tarihi: 19.07.20

Kabul Tarihi: 14.05.21

Erken Görünüm: 28.08.21

\title{
Duygusal Bağlılık, Örgüt Kaynaklı Öz Saygı, Örgütsel Adalet ve Destek Arasındaki İlişkilerin İncelenmesi
}

\author{
Şule Polat $(\mathrm{D}) 1$
}

$\ddot{O} \mathbf{z}$

Giriş: Çalışanlar üzerinde önemli etkileri olan örgütsel davranışlar görme yetersizliği olan öğretmenler bakımından daha hassas bir durum oluşturmaktadır. Bu çalışmada, ilköğretim ve ortaöğretim kurumlarında görevli görme yetersizliği olan öğretmenlerin görüşlerine göre örgütsel adalet, duygusal bağlılık, örgüt kaynaklı öz sayg1 ve algılanan örgütsel destek arasındaki ilişkiler incelenmesi amaçlanmaktadır.

Yöntem: Örneklemi 2018-2019 eğitim-öğretim yılında ilköğretim ve ortaöğretim kurumlarında görevli 154 görme yetersizliği olan öğretmenden oluşmaktadır. Çalışmada, ilişkisel tarama yöntemi kullanılmış ve veriler nicel teknikler aracılığıyla çözümlenmiştir. "Duygusal Bağlılık Ölçeği, Örgütsel Destek Ölçeği, Örgütsel Adalet Algısı Ölçeği, Örgüt Kaynaklı Öz sayg1 Ölçeği” veri toplama aracı olarak kullanılmıştır. Veri analizinde aritmetik ortalama, standart sapma ve parametrik testler uygulanmıştır.

Bulgular: Bulgular, öğretmenlerin örgütsel destek algı düzeylerinin erkek öğretmenler ve evli öğretmenler lehine farklılaştığını göstermiştir. Ayrıca öğretmenlerin örgüt kaynaklı özsaygı algı düzeylerinin de erkek öğretmenler lehine farklılaştığını göstermiştir. Örgütsel adalet algısı ile örgüt kaynaklı öz saygı arasında, örgütsel adalet algıları ile algılanan örgütsel destek arasında ve duygusal bağlılık ile örgüt kaynaklı öz saygı arasında anlamlı ilişki olduğu görülmüştür. Sonuç olarak; örgüt kaynaklı öz sayg1, örgütsel adalet algısı ve duygusal örgütsel bağl1lı̆̆ı, örgütsel destek algısının anlamlı yordayıcıları olduğu saptanmıştır.

Tartışma: İlköğretim ve ortaöğretim kurumlarında görevli görme yetersizliği olan öğretmenlerin okullarına olan duygusal bağlılıklarının orta düzeyde olduğu görülmüştür. Görme yetersizliği olmayan öğretmenlerle yapılan çalışmalar da benzer sonuçlar çıkması, görme yetersizliğinin öğretmenlerde duygusal bağlılığı etkilemediğini göstermektedir. Alanyazın incelendiğinde okul yöneticilerinin görme yetersizliği olan öğretmenle çalışmaya çok istekli olmamalarına karşın öğretmenlerine destek verdikleri anlaşılmaktadır. Okullarda örgütsel adaletin sağlanması durumunda örgütsel desteğin ve örgüt kaynaklı özsaygının arttığı bu çalışma ile bir kez daha görülmektedir.

Anahtar sözcükler: Öğretmen, görme yetersizliği, örgütsel adalet, örgütsel destek, duygusal bağl1lık, örgütsel davranış.

Atıf için: Polat, Ş. (2022). Duygusal bağlılık, örgüt kaynaklı öz sayg1, örgütsel adalet ve destek arasındaki ilişkilerin incelenmesi. Ankara Üniversitesi Eğitim Bilimleri Fakültesi Özel Eğitim Dergisi, 23(2), $345-$ 364. https://doi.org/10.21565/ozelegitimdergisi.771552

1Dr., Milli Eğitim Bakanlığı, E-posta: sule.polat@yahoo.com, https://orcid.org/0000-0001-5469-5758 


\section{Giriş}

Eğitim örgütlerinde öğretmenlerin verimliliğinin ve motivasyonunun artırılmasının gerekliliği, örgütün başarısı için tartışılmazdır. Bununla birlikte okullarda öğretmenlerin okul içinde daha mutlu ve verimli olmaları için neler yapılması gerektiği araştırmacıların ilgisini çeken bir konudur. Hele ki engelli öğretmenlerin okul ortamlarında daha görünür olmaları, öğrenci, öğretmen ve yönetim tarafından kabul görmeleri gerekmektedir. Dünya çapında 36 milyonu kör olan 253 milyon insan görme bozukluğu yaşamaktadır (Dünya Sağlık Örgütü, 2018). Görme yetersizliği olan bireylerin 1980-1990 yıllarından itibaren meslek grubu üyesi oldukları bilinmektedir (Revathi \& Naomi, 2016). Engellilere yönelik yönetici tutumları çalışmalarında, görme yetersizliği olan çalışanların maruz kaldığı zorlukların farklı engel gruplarına sahip çalışanlara kıyasla yüksek olduğu tespit edilmiştir (Gilbride vd., 2000). Ayrıca yönetici tutumlarının görme yetersizliği olan öğretmenlere karşı orta düzeyde olumlu olduğu bilinmektedir (Restad, 1972). Benzer bir bulgu da yöneticilerin görme yetersizliği olan öğretmenlerle çalışmayı orta düzeyde istedikleridir (Revathi \& Naomi, 2016). Buna karşın engelli okullarında çalışan engelli öğretmenlerin velilere daha çok güven verdiği, öğretmen beklentilerinin düşük olmasının, velileri rahatlattığını gösteren çalışma bulgularına da rastlanmıştır (Ferri vd., 2001). Engelli öğretmenler üzerine yapılan çeşitli çalışmalarda; öğretmenlerin engel durumlarının öğrencilerin zihinsel, duygusal ve sosyal gelişimlerinde faydalı olduğu (Valle vd., 2004), öğrenciler ve aileleri için şefkat duygularının gelişimi için yardımcı olduğu ifade edilmiştir (Vogel vd., 2007). Engelli öğretmenler, meslektaşlarının ve yöneticilerinin olumlu bakışını kazanabilmek için, performanslarının üstünde emek harcadıklarını belirtmektedirler (Hazen, 2012). Eğitimde Görme Engelliler Derneğinin (EGED, 2017) gerçekleştirdiği bir araştırmada görme yetersizliği olan öğretmenlerin zümre öğretmenleri, öğrenci velileri, yardımcı personel ve meslektaşları ile iletişimlerinin çoğunlukla işbirliği içinde tespit edilmiştir. Aynı çalışmada engelli öğretmenlerin \%20’ye yakın bir oranda yıldırmaya (mobbing) maruz kaldığı ve \%17'sinin yöneticileriyle ilişkilerinin olumlu olmadığı görülmüştür. Brandsborg ve diğerleri (2001), görme yetersizliği olan öğretmenin görme yetersizliği olan öğrencinin konforlu bir hayat sürmesini sağlayan bilgiyi öğrettiğini, ortak bir kimliğe sahip oldukları için daha güvenilir bir rol model olacağını çalışmaları 1şı̆̆ında savunmaktadır. Ayrıca yine Brandsborg ve diğerleri (2001), görme yetersizliği olan öğretmenlerin fiziksel hareket gerektiren durumlarda dezavantajlı, ancak öğretmen ve öğrencinin görme yetersizliği olduğu durumlarda daha yakın iletişim içinde oldukları tespitlerinde bulunmuşlardır.

5825 sayılı kanunla (3/12/2008 tarihli) onaylanmış olan "Engellilerin Haklarına İlişkin Sözleşme”nin 27 'nci maddesinde “İşe alım ve istihdam edilme koşullarında, istihdamın sürekliliği, kariyer gelişimi ve sağlıklı ve güvenli çalışma koşulları dâhil olmak üzere, istihdama ilişkin her hususta, engelliliğe dayalı ayrımcılığı yasaklar" denilmektedir. Anayasa'nın Eşitlik İlkesi, 5378 sayılı Engelliler Kanunu ve Ceza Kanunu'nun 122'nci maddesi gereğince de ayrımcılık yasaklanmıştır. Öte yandan iş alımında örgütlerin engelli birey çalıştırma zorunluluğu, merkezi sınavlarda ek süre verilmesi, engelli memur alımı sınavlarının yapılması gibi pozitif ayrımcılık kapsamında uygulamalar da bulunmaktadır. Türkiye verilerine göre istihdam edilen 53017 engelli memur ve 10450 görme yetersizliği olan memur bulunmaktadır (Türkiye Cumhuriyeti Devlet Personel Başkanlığı, 2018). Milli Eğitim Bakanlığı'nda istihdam edilen 3925 engelli öğretmen bulunmakta ve yaklaşık olarak 1000 civarında görme yetersizliği olan öğretmen olduğu tahmin edilmektedir (EGED, 2017). Bu çerçevede engelli çalışanlar içerisinde görme yetersizliği olanlar önemli bir yer (\%17-\%20) tutmaktadır. Görme yetersizliği olan öğretmenlerin okullarında desteklenmeleri, adaletle yaklaşılmaları, öz saygılarını kaybetmemeleri ve okullarına bağlılıklarının devam etmesi, eğitimin amacına ulaşması için çok önemlidir. Görme yetersizliği olan öğretmenin öğrencisine ulaşmasında örgütünün desteği büyük önem arz etmektedir.

Alanyazında örgütsel desteğe ilişkin tanımlar bulunmaktadır. Bu tanımlardan en çok bilineni, Eisenberger ve diğerlerinin (1986) “örgütün çalışanların katkılarına değer ve mutluluklarına önem verdiği ve örgütün çalışanlarını etkileyen eylem ve politikalarını gönüllü bir biçimde gerçekleştirdiğine ilişkin algı” tanımlamasıdır. Aselage ve Eisenberger'e (2003) göre çalışanlar, örgütlerinde yaşadıkları olumlu ve olumsuz durumları idarecilerinin tutum ve davranışları ile ilişkilendirdikleri bilinmektedir. Beheshtifar ve Herat'e (2013) göre ise; örgütsel destek, "çalışanların algısına göre; yöneticilerin, çalışanların örgüte katkılarını görmeleri ve refahlarını düşünmeleri” olarak tanımlanmaktadır. Bu algıyı, örgütlerin çalışanını kabulü, samimiyeti ve çalışanın iş yerindeki çabası ile kazandığı maddi- manevi ödüller belirlemektedir.

Rhoades ve Eisenberger (2002), 70 çalışmayı inceledikleri araştırmalarında örgütsel adalet ve örgütsel destek arasında yüksek düzeyde ilişki olduğunu ifade etmiştir. Benzer bir çalışmada da algılanan örgütsel desteğin, örgütsel adalet algısını yordadığı bulunmuştur (Önderoğlu, 2010). Ayrıca Nayır $(2011,2012)$ örgütsel desteğin örgütsel bağlılığı yordadığını belirtmiştir. Örgütsel bağlılık ile örgütsel destek arasında pozitif yönlü yüksek 
düzeyde ilişki saptanmıştır (Kaplan \& Öğüt, 2012). Ayrıca müdür desteğinin ve güveninin öğretmenlerin örgütsel bağ lığını artırdığı görülmüştür (Demirtaş vd., 2017).

Çalışanların örgütsel bağllıklarının daha yüksek iş performansı sağladığı bilinmektedir (Arshadi \& Hayavi, 2013). Aqeel ve Ahmed (2014), çalışanlarda örgütsel bağlllığın yüksek olduğu durumda, iş performanslarının artırdığını ve örgütsel hedeflere ulaşılması için "gönülllü" sorumluluk aldıklarını belirtmektedir. Eisenberger ve diğerleri (1986), örgütsel bağlllı̆̆ işveren ve çalışanlar arasında bir sosyal alışveriş olarak tanımlamaktadır ve örgütlerin çalışanlarına olan bağlılıkları (algılanan örgütsel destek), çalışanların örgütlerine olan bağlılıklarına katkıda bulunduğunu ifade etmektedir.

Örgütsel bağlllık kavramı, Mowday ve diğerleri (1982) tarafından "bir kişinin örgüt ile kimliğinin özdeşleşme gücü" olarak tanımlanmıştır. Ayrıca "devam bağlılı̆̆ı, normatif bağlılık ve duygusal bağlılık" olarak üç çeşit örgütsel bağllılktan bahsedilmektedir (Meyer \& Allen, 1991). Kavramların ifade ettiği anlamlar incelendiğinde; devam bağlılığının örgütten ayrılmanın getireceği maliyetin farkındalığıyla ilgili olduğu görülmektedir. Örgütle ilişkisi devam bağlılığına dayanan çalışanların, maddi doyuma ve iş doyumuna ihtiyaç duydukları için örgütte kaldığı düşünülmektedir (Meyer \& Allen, 1991). Normatif bağl1lıkta ise çalışan, örgütünde çalışması gerektiğinin doğruluğuna inanmaktadır. Çalışan ve örgüt arasındaki ilişkiler psikolojik sözleşmeye bağlı olarak da gelişebilmektedir.

Duygusal bağlanma, çalışanın örgütü ile duygusal bağını ve onunla özdeşleşmesini ifade etmektedir. Bu bağlanma türünde, çalışan kendini örgütü ile bütünleştirmekte ve örgütünü çok önemsemektedir (Allen \& Meyer, 1990). Gül (2003), çalışanların örgütsel değerleri ve amacını kabullenmesini ve örgüt yararına insanüstü gayret göstermesi olarak ifade etmektedir. Örgütüne duygusal bağlllığı olan çalışan için örgüt büyük anlam taşımakta ve çalışan örgütte kalmak istemektedir. Gürbüz (2006) de duygusal bağllllı̆̆ "örgütsel amaç ve değerlere olan inanç ve bunların güçlü şekilde kabulü, örgüt yararına daha fazla çaba sarf etmeye gönüllü olma, örgütsel üyeliği devam ettirme konusunda güçlü bir arzunun varlığı" olarak özetlemiştir.

Duygusal bağlılık faktörleri "iş güçlüğü, rol açıklığı, amaç açıklığı, amaç güçlüğü, yönetimin öneriye açıklı̆̆ı, arkadaş bağlılığı, örgütsel bağımlılık, eşitlik, kişisel önem, dönüt, katılım” olarak sayılmaktadır (Allen \& Meyer, 1990). Bu bağlamda görevin zor ve heyecanlı bir iş olması, örgütün beklentilerinin açık olması, örgütün amacının çalışanlarca bilinmesi, arkadaş ilişkileri, çalışanlara eşit davranılması, çalışana değer verilmesi, çalışana çalışması ile ilgili dönüt verilmesinin duygusal bağlılı̆̆ artırıcı faktörler olduğu anlaşılmaktadır. Yüksek duygusal bağlılığı olan çalışanların sayısının çok olması, iş ortamında daha az devamsızlık ve daha yüksek iş motivasyonunu getirmektedir (Çetin, 2004).

İnsanın kendine duyduğu saygı olarak tanımlanan öz sayg1, bireylerinin "öz"lerini yani kendilerini değerlendirmelerini, dolayısıyla kendi benliklerini beğenme, önemli görme ve kabul etme durumlarını ifade etmektedir (Türk Dil Kurumu, t.y.). Öz saygısı yüksek olan bireylerin toplum içerisinde daha aktif olduğu ve kendilerini iyi ifade ettikleri; buna karşın öz saygısı düşük olanların ise çoğunlukla kendilerini değersiz, güçsüz ve çaresiz olarak görme eğilimi içerisinde oldukları ve kaygı düzeylerinin de yüksek olduğu ifade edilmektedir (Çetin, 2004; Çiğdemoğlu, 2006). Öz saygı durağan değildir ve şartlara göre değişebilir. Kişinin öz saygısındaki değişim, olaylar karşısındaki tepki ve davranışlarında da değişikliklere neden olmaktadır (Başkara, 2002).

Korman'ın (1970), çalışanlarda öz saygı kavramını inceleyen ilk araştırmacı olduğu görülmektedir. Kavramı ilk kullanan araştırmacılar olarak Pierce ve diğerleri (1989), örgüt kaynaklı öz saygıyı "çalışanın örgütteki rolleri ile ihtiyaçlarının tatmin edildiğine yönelik inanç düzeyi” olarak tanımlanmaktadırlar. Hui ve Lee (2000) çalışmalarında örgüt kaynaklı öz saygısı düşük olan çalş̧anların örgütsel bağlılıklarının da düşük olduğu ve bu kişilerde yüksek iş devamsızlığı olduğu sonucuna ulaşmışlardır. Carson ve diğerleri (1997) örgüt kaynaklı öz saygının çalışanların örgütsel bağ lılığını artırdığını tespit etmiştir. Bunun yanında bazı araştırmalarda örgüt kaynaklı öz saygısı yüksek olan çalışanların, iş motivasyonlarının yüksek olduğu, işbirliğine açık oldukları, iş performanslarının yüksek olduğu ve örgütleri için özverili oldukları ortaya koyulmuştur (Dyne vd., 1994; Kuo, 2013).

Örgüt kaynaklı öz saygı çalışanların "işyerinde hissedecekleri değer veya değer duyguları" olarak tanımlanabilir (Payne, 2007, s. 237). Örgüt kaynaklı öz saygı, çalışanların kendi örgütlerinde "önemi, anlamlılığı, etkililiği, yetkinliği ve değerliliği" hakkındaki kendilerine ilişkin algılarını yansıtmaktadır (Chan vd., 2013). Pierce ve Gardner (2004), düşük örgüt kaynaklı öz saygısı olan çalışanların verimliliklerinin azaldığını ve işten ayrılma niyeti taşıdıklarını, "örgütün önemli bir parçası" olduklarını fark eden çalışanların ise etkililik ve etkinliklerinin arttı̆ını belirtmişlerdir. 
Greenberg (1990) kazanımların adil bir şekilde dağıtılması, yöneticilerin çalışanlarına adil davranması ve örgüt içi düzenleme, uygulama ve kararlarda adaletli olunduğuna ilişkin çalışan algısının karşılı̆̆ında kullanılan örgütsel adalet kavramını ilk kullanan kişidir. Greenberg (1990) örgütsel adalet ile birçok örgütsel davranışın açıklanabileceğini savunmaktadır. Moorman ve diğerlerine (1998) göre ise; örgütsel adalet, doğrudan işyeri ile ilişkili olan adaleti tanımlamaktadır ve çalışanların hangi durumlarda kendilerine adil davranıldı̆̆ını düşündükleri ve bunun işle ilgili diğer hususları ne yönde etkilediği ile ilgili bir kavramdır. Kaneshiro (2008) örgütsel adalet algısını; mesai, yetki, görev, çalışma ortamı, ceza, ödül, ücret gibi değişkenlerle, çalışanların yönetsel değerlendirme ve karar süreçlerini algılanma biçimi olarak ifade etmektedir. Örgütsel adaletin örgüt içinde tesis edilmesi durumunda, çalı̧̧anlar örgüt içinde kendilerini değerli görmekte ve örgütsel etkililik ile verimlik artmaktadır (İyigün, 2012). Cesur ve Erol (2020), okul yönetiminde kayırmacılık davranışının örgütsel adalet ile negatif yönlü bir ilişkisi olduğunu belirtmiştir. Jeon (2009) ile Sholihin ve Pike (2010), çalışmalarında örgütsel adaletin, örgütsel güveni artırdığını; Gürbüz (2006) ve Songür ve diğerleri (2008) örgütte adaletin, örgütte vatandaşlık davranışını artırdığını tespit etmişlerdir.

Örgütlerin çalışanlarına yönelik tutumlarının çalışanların örgütlerine yönelik tutumları üzerindeki etkilerini inceleyen çalışmalara bakıldığında; algılanan örgütsel destek, örgütsel adalet algısı, duygusal bağlılık ve örgüt kaynaklı öz saygı değişkenlerinin ayrı ayrı veya ikişer değişken olarak gerek ulusal gerekse de uluslararası alanyazında ilgi gösterilen ve ele alınan konular olduğu görülmektedir (Derinbay, 2011; Köse, 2016; Rhoades \& Eisenberger, 2002). Örgütsel davranış alanyazını incelendiğinde görme yetersizliği olan öğretmenler üzerine sınırlı sayıda çalışma bulunmakla beraber (Polat, 2017; Yüner, 2018) var olan çalışmalarda bu araştırma kapsamında ele alınan değişkenlerin beraber incelendiği çalışmaya rastlanmamıştır. Bu araştırma görme yetersizliği olan öğretmen görüşlerine bağlı olarak ilköğretim ve ortaöğretim kurumlarında görevli görme yetersizliği olan öğretmenlerin görüşlerine göre örgütsel adalet, duygusal bağlılık, örgüt kaynaklı öz saygı ve algılanan örgütsel destek arasındaki ilişkilerin incelenmesini amaçlamaktadır. Bu kapsamda aşağıdaki problem cümleleri oluşturulmuştur.

1. Görme yetersizliği olan öğretmenlerin örgütsel destek, duygusal bağl1lı, örgüt kaynaklı öz saygı ve örgütsel adalet algıları nasıldır?

2. Görme yetersizliği olan öğretmenlerin örgütsel destek, duygusal bağlılık, örgüt kaynaklı öz saygı ve örgütsel adalet algıları arasında anlamlı bir ilişki var mıdır?

3. Görme yetersizliği olan öğretmenlerin örgütsel destek, duygusal bağl1lı, örgüt kaynaklı öz saygı ve örgütsel adalet algıları medeni durum, cinsiyet ve meslekte çalışma süresine göre anlamlı bir farklılık göstermekte midir?

4. Görme yetersizliği olan öğretmenlerin örgütsel adalet algıları, duygusal bağlllık ve örgüt kaynaklı öz saygıları örgütsel destek algılarının anlamlı yordayıcısı mıdır?

\section{Yöntem}

\section{Araştırma Yöntemi}

Çalı̧̧mada, ilişkisel tarama yöntemi kullanılmış ve veriler nicel teknikler aracıllı̆ı̆ıla çözümlenmiştir. Karasar (1994), ilişkisel tarama modelini "iki ve daha çok sayıdaki değişken arasında birlikte değişim varlığını ve/veya derecesini belirlemeyi amaçlayan araştırma modeli” olarak nitelendirmiştir. Araştırmanın bağımlı değişkeni "algılanan örgütsel destek" ve bağımsız değişkenleri ise "duygusal bağlllık, örgütsel adalet ve örgüt kaynaklı özsaygı" olarak belirlenmiştir.

\section{Evren ve Örneklem}

2018-2019 eğitim öğretim yılında Türkiye'nin tüm şehirlerinde resmi ilköğretim ve ortaöğretimde görevli toplam 3925 görme yetersizliği bulunan öğretmen araştırmanın evrenini oluşturmaktadır. Örneklem seçiminde örneklem büyüklükleri tablosundan yararlanılarak örneklem seçimi yapılmıştı. Evren 0.02 güvenirlik ile $\% 10$ hata payı hesaplamasıyla örneklem büyüklüğ̈̈ 131 görme yetersizliği olan öğretmen ile sağlandığı saptanmıştır (Yazıcıŏglu \& Erdoğan, 2004). Öğretmenler rastgele (random) seçilmiştir. Ölçekler görme yetersizliği olan 154 öğretmene uygulanmıştır. Bunlardan 82 öğretmenle yüz yüze görüşülmek, kalan 72 öğretmenle ise telefon görüşmesi yapılmak suretiyle, ölçek kendilerine okunmuş ve öğretmenlerden alınan yanıtlar ölçeğe kaydedilmiştir. Öğretmenlerin 79'u (\%51) erkek ve 75'i (\%49) kadındır. Meslekte 1 ve 7 yıl arası çalışanlar 69, 8 ve 14 yıl arası çalışanlar 42, 15 ve 22 yıl arası çalışanlar 27 ve 22 yıl üzeri çalışanların sayısı 16'dır. Öğretmenlerin 85 'i evli, 69'u bekârdır. 


\section{Veri Toplama Araçları}

\section{Duygusal Bağlllık Ölçeği}

Araştırmada Meyer ve diğerleri (1993) tarafından geliştirilen ve Akalın (2006) tarafından Türkçeye uyarlanmış olan "Duygusal Bağlılık Ölçeği" kullanılmıştır. Toplam 6 maddeden oluşan ve 7'li likert olarak (kesinlikle katılmıyorum-kesinlikle katılıyorum aralığında) hazırlanmış olan ölçek, tek boyuttan oluşmaktadır. Ölçekten yüksek puan alınması, çalışanın örgütüne yüksek duygusal bağlılığı olduğu şeklinde yorumlanmaktadır. Ölçekten alınabilecek en yüksek puan 42, en düşük puan 6'dır. Akalın (2006) ölçeğin Cronbach alfa değerini .80 olarak hesaplamıştır. Mevcut çalışmada Cronbach alfa değeri .70 bulunmuştur. Ölçek toplam varyansın \%45'ini açıklamaktadır. Ölçeğin yapı geçerliği doğrulayıcı faktör analizi (DFA) ile test edilen çalışmada, ölçeğin tek boyutlu olduğu ve " $x^{2}=26.65, s d=9, x 2 / s d=2.96, A G F I=.96, G F I=.98, N F I=.96, C F I=.97, I F I=.97, R M R$ $=.084$, RMSEA $=.113$ " değerlerini aldığ hesaplanmıştır.

\section{Örgütsel Destek Ölçeği}

Eisenberger ve diğerleri (1986) tarafından geliştirilen ve Akalın (2006) tarafından Türkçeye uyarlanmış olan “Örgütsel Destek Ölçeği”, sekiz maddeli kısa bir formdur. Tek boyutlu, 5'li Likert (kesinlikle katılmıyorumkesinlikle katılıyorum aralığında) yapılıdır. Ölçekten yüksek puan alınması, çalışanın örgütten yüksek destek gördüğg̈ şeklinde yorumlanmaktadır. Ölçekten alınabilecek en yüksek puan 40, en düşük puan 8'dir Akalın (2006) ölçeğin Cronbach alfa değerinin .87 olduğunu bulmuştur. Bu çalışmada Cronbach alfa değerinin .70 olduğu görülmüştür. Ölçek toplam varyansının \%55'ini açıklamaktadır. Ölçeğin yapı geçerliği DFA ile test edilen çalışmada, ölçeğin tek boyutlu olduğu ve " $x^{2}=100.48, s d=20, x^{2} / s d=5, A G F I=.92, G F I=.96, N F I=.92, C F I$ $=.93, I F I=.93, R M R=.20, R M S E A=.17 ”$ değerlerini aldığı hesaplanmıştır.

\section{Örgütsel Adalet Algısı Ölçeği}

Güneş (2011) tarafından Türkçeye uyarlanan ve Hoy ve Tarter (2004) tarafından geliştirilen "Örgütsel Adalet Algısı Ölçeği”" kısa formu on maddelidir. Tek boyutlu, 5'li Likert (kesinlikle katılmıorum-kesinlikle katılıyorum aralığında) yapılıdır. Ölçekten yüksek puan alınması, çalışanın örgütten yüksek örgütsel adalet algısı gördüğü şeklinde yorumlanmaktadır. Ölçekten alınabilecek en yüksek puan 50, en düşük puan 10'dur Güneş (2011) ölçeğin Cronbach alfa değerini .91 olarak hesaplamıştır. Mevcut çalışmada Cronbach alfa değeri .94 bulunmuştur. Ölçek toplam varyansın \% 75 'ini açıklamaktadır. Ölçeğin yapı geçerliği DFA ile test edilen çalışmada, ölçeğin tek boyutlu olduğu ve " $x^{2}=104.27, s d=35, x^{2} / s d=3.17, A G F I=.99, G F I=.99, N F I=.99$, $C F I=.99, I F I=.99, R M R=.024, R M S E A=.11$ ” değerlerini aldığ 1 hesaplanmıştır.

\section{Örgüt Kaynaklı Öz Saygı Ölçeği}

Pierce ve diğerleri (1989) tarafından geliştirilmiş ve Akalın (2006) tarafından Türkçeye uyarlanmış olan “Örgüt Kaynaklı Özsaygı Ölçeği” kullanılmıştır. Toplam 10 maddeden oluşan ve 7’li Likert olarak (kesinlikle katılmıyorum-kesinlikle katılıyorum aralığında) hazırlanmış olan bu ölçek, tek boyuttan oluşmaktadır. Ölçekten alınabilecek en yüksek puan 70, en düşük puan 10'dur. Akalın (2006) ölçeğin Cronbach alfa değerini .93 hesaplamıştır. Mevcut çalışmada Cronbach alfa değeri .83 bulunmuştur. Ölçe toplam varyansın \%70'ini açıklamaktadır. Ölçeğin yapı geçerliği DFA ile test edilen çalışmada, ölçeğin tek boyutlu olduğu ve " $x^{2}=118.19$, $s d=35, x^{2} / s d=3.37, A G F I=.60, G F I=.77, N F I=.71, C F I=.74, I F I=.77, R M R=.013, R M S E A=.11$ " değerlerini aldığı hesaplanmıştır.

\section{Veri Toplama ve Analizi}

Veri analizinde aritmetik ortalama, standart sapma ve parametrik ( $t$ test, Anova, korelasyon, çoklu regresyon) testler uygulanmıştır. Ölçek maddelerinin toplam puan ortalamasına göre bakılan normallik testinin sonuçları basıklık ve çarpıklık değerlerinin .05 anlamlılık düzeyi ile hesaplanmıştır. İşleme göre çarpıklık (skewness) ile basıklık (kurtosis) değeri örgütsel destek için (-.37, -.10), duygusal bağlllığa göre (-.18, -1.1), örgüt kaynaklı öz saygıya göre $(-.82,-3.00)$ ve örgütsel adalet algısına göre $(-.43,-.87)$ şeklindedir. Box M Testiyle ölçeklerin homojenliği test edilmiştir. Veri setinde uç değerler bulunmamaktadır. Büyüköztürk (2007) basıklık ve çarpıklık katsayıları, \pm 3 arasında ise normal dağılım sergilediğini varsaymaktadır. Bu sonuçlara bağlı olarak parametrik testlerin kullanılması uygun bulunmuştur. Ölçeklerle ilgili algı seviyeleri standart sapma ve aritmetik ortalama puanlarına göre değerlendirilmiştir. 5’li Likert ölçeklerde "1.0 - 1.80" arası çok düşük, "1.81 - 2.60" arası düsük, "2.61 - 3.40" arası orta, "3.41 - 4.20" arası yüksek, "4.21 - 5.0" arası çok yüksek olduğu kabul edilmiştir. 7’li Likert ölçeklerde "1.00 - 2.20" arası çok düşük, "2.21 - 3.40" arası düşük, "3.41 - 4.60" arası orta, "4.61 - 
5.80" arası yüksek ve "5.81 - 7.00" arası çok yüksek olduğu varsayılmıştır. Korelasyon tablosu ise 0 - .30" arası zaylf, ".31 - .60" arası orta ve ".61 - 1.0" arası yüksek ilişkili değerlendirilmiştir (Büyüköztürk, 2007).

\section{Bulgular}

Görme Yetersizliği Olan Öğretmenlerin Örgütsel Destek, Duygusal Bağlılık, Örgüt Kaynakı Öz Saygı ve Örgütsel Adalet Algıları

Görme yetersizliği olan öğretmenlerin örgütsel destek, duygusal bağlllık, örgüt kaynaklı öz saygı ve örgütsel adalet algılarının belirlenebilmesi için Örgütsel Destek Ölçeği, Duygusal Bağlllık Ölçeği, Örgüt Kaynaklı Öz Saygı Ölçeği ve Örgütsel Adalet Algısı Ölçeğinden aldıkları puanlar incelenmiştir. Bu bağlamda belirtilen ölçeklerden öğretmenlerin aldıkları puanların aritmetik ortalama ve standart sapma değerleri hesaplanarak bulgular Tablo 1'de gösterilmiştir.

\section{Tablo 1}

Görme Yetersizliği Olan Öğretmenlerin Örgütsel Destek, Duygusal Bağlllık, Örgüt Kaynaklı Öz Saygı ve Örgütsel Adalet Algılarına İlişkin Betimsel İstatistikler

\begin{tabular}{lccc}
\hline \multicolumn{1}{c}{ Değişken } & $n$ & $\bar{X}$ & $S S$ \\
\hline Örgütsel Destek Ölçeği & 154 & 4.53 & 1.05 \\
Duygusal Bağlılık Ölçeği & 154 & 4.39 & 1.11 \\
Örgüt Kaynaklı Öz Saygı Ölçeği & 154 & 5.35 & .86 \\
Örgütsel Adalet Algısı Ölçeği & 154 & 3.43 & 1.09 \\
\hline
\end{tabular}

Tablo 1'de görüldüğü üzere öğretmenlerin örgütsel adalet alg1 düzeyleri $\bar{X}=3.43(S S=1.09)$, örgüt kaynaklı öz saygı düzeyleri $\bar{X}=5.35(S S=.86)$, örgütsel destek algı düzeyleri $\bar{X}=4.53(S S=1.05)$ ve duygusal bağlılık düzeyleri $\bar{X}=4.39$ 'dur ( $S S=1.11$ ). Örgütsel adalet algısı yüksek, örgüt kaynaklı öz saygı algı düzeyi yüksek, örgütsel destek algı düzeyi çok yüksek ve duygusal bağlılık algı düzeyi orta düzeydedir.

\section{Görme Yetersizliği Olan Öğretmenlerin Örgütsel Destek, Duygusal Bağlılık, Örgüt Kaynakı Öz Saygı ve Örgütsel Adalet Algıları Arasındaki İlişki}

Görme yetersizliği olan öğretmenlerin Örgütsel Destek Ölçeği, Duygusal Bağlılık Ölçeği, Örgüt Kaynaklı Öz Saygı Ölçeği ve Örgütsel Adalet Algısı Ölçeğinden aldıkları toplam puanlar arasında anlamlı bir ilişki olup olmadığına iliş̧kin Pearson Korelasyon analizi yapılmış ve sonuçlar Tablo 2'de verilmiştir.

\section{Tablo 2}

Görme Yetersizliği Olan Öğretmenlerin Örgütsel Destek, Duygusal Bağlllık, Örgüt Kaynaklı Öz Saygl ve Örgütsel Adalet Algiları Arasinda Korelasyon Analizi

\begin{tabular}{llccc}
\hline \multicolumn{1}{c}{ Değişken } & 1 & 2 & 3 & 4 \\
\hline 1. & Duygusal Bağlılık Ölçeği & 1 & & \\
2. & Örgütsel Destek Ölçeği & $.25^{*}$ & 1 & \\
3. Örgütsel Adalet Algısı Ölçeği & .16 & $.78^{*}$ & 1 & $.41^{*}$ \\
$4 . \quad$ Örgüt Kaynaklı Öz Saygı Ölçeği & .09 & $.63^{*}$ & 1 \\
\hline${ }^{*} p .01$ & & &
\end{tabular}

Tablo 2'de görüleceği üzere öğretmenlerin örgütsel adalet algıları ile örgüt kaynaklı öz saygıları arasında orta düzeyde, pozitif yönlü ve anlamlı bir ilişki $(r=.41, p<.01)$ vardır. Benzer şekilde öğretmenlerin örgütsel destek ile örgütsel adalet algıları arasında yüksek düzeyde, pozitif yönlü ve anlamlı $(r=.78, p<.01)$, örgüt kaynaklı öz saygıları arasında yüksek düzeyde, pozitif yönlü ve anlamlı $(r=.63, p<.01)$ ve duygusal bağlılıkları arasında zayıf düzeyde, pozitif yönlü ve anlamlı $(r=.25, p<.01)$ ilişsi bulunmaktadır.

\section{Görme Yetersizliği Olan Öğretmenlerin Örgütsel Destek, Duygusal Bağıılık, Örgüt Kaynakı Öz Saygı ve} Örgütsel Adalet Algılarının Medeni Durum, Cinsiyet ve Meslekte Çalışma Süresine Göre Karşılaştırılması

Görme yetersizliği olan öğretmenlerin örgütsel destek, duygusal bağl1lık, örgüt kaynaklı öz saygı ve örgütsel adalet algılarının cinsiyet ve medeni durumlarına göre göre anlamlı farklılık gösterip göstermediğine bağımsız örneklemler $t$ testi ile ve meslekte çalışma süresine göre anlamlı farklılık gösterip göstermediğine ise tek yönlü varyans analizi (ANOVA) ile bakılmıştır. Bağımsız örneklemler t testine ilişkin sonuçlar Tablo 3'te ANOVA'ya ilişkin sonuçlar ise Tablo 4'te sunulmuştur. 
Tablo 3

Öğretmenlerin Örgütsel Destek, Duygusal Bağlllık, Örgüt Kaynaklı Öz Saygl ve Örgütsel Adalet Alglarınin, Cinsiyet ve Medeni Duruma Göre Anlamlı Farklılık Gösterip Göstermediğine İlişkin Bağımsız Örneklemler t Testi Sonuçları

\begin{tabular}{|c|c|c|c|c|c|c|c|c|}
\hline Ölçek & Değişken & & $n$ & $\bar{X}$ & $S S$ & $s d$ & $t$ & $p$ \\
\hline \multirow{2}{*}{ Duygusal Bağlılık Ölçeği } & \multirow{8}{*}{ Cinsiyet } & Kadın & 75 & 4.23 & 1.08 & \multirow{2}{*}{152} & \multirow{2}{*}{-1.73} & \multirow{2}{*}{.09} \\
\hline & & Erkek & 79 & 4.54 & 1.13 & & & \\
\hline \multirow{2}{*}{ Örgütsel Destek Ölçeği } & & Kadın & 75 & 4.23 & 1.13 & 152 & -357 & 00 \\
\hline & & Erkek & 79 & 4.81 & .88 & 102 & ו & .00 \\
\hline \multirow{2}{*}{ Örgütsel Adalet Algısı Ölçeği } & & Kadın & 75 & 3.26 & 1.17 & \multirow{2}{*}{152} & \multirow{2}{*}{-1.91} & \multirow{2}{*}{.06} \\
\hline & & Erkek & 79 & 3.60 & .98 & & & \\
\hline \multirow{2}{*}{ Örgüt Kaynaklı Öz Saygı Ölçeği } & & Kadın & 75 & 5.19 & .93 & \multirow{2}{*}{152} & \multirow{2}{*}{2.27} & \multirow{2}{*}{.03} \\
\hline & & Erkek & 79 & 5.50 & .76 & & & \\
\hline \multirow{2}{*}{ Duygusal Bağlılık Ölçeği } & \multirow{6}{*}{$\begin{array}{l}\text { Medeni } \\
\text { durum }\end{array}$} & Evli & 85 & 4.57 & 1.06 & \multirow{2}{*}{152} & \multirow{2}{*}{2.13} & \multirow{2}{*}{.02} \\
\hline & & Bekâr & 69 & 4.16 & 1.14 & & & \\
\hline \multirow{2}{*}{ Örgütsel Destek Ölçeği } & & Evli & 85 & 4.42 & 1.08 & \multirow{2}{*}{152} & \multirow{2}{*}{-1.33} & \multirow{2}{*}{.18} \\
\hline & & Bekâr & 69 & 4.65 & 1.01 & & & \\
\hline \multirow{2}{*}{ Örgütsel Adalet Algısı Ölçeği } & & Evli & 85 & 3.34 & 1.18 & \multirow{2}{*}{152} & \multirow{2}{*}{-1.2} & \multirow{2}{*}{.23} \\
\hline & & Bekâr & 69 & 3.55 & .96 & & & \\
\hline \multirow{2}{*}{ Örgüt Kaynaklı Öz Saygı Ölçeği } & & Evli & 85 & 5.29 & .70 & \multirow{2}{*}{152} & \multirow{2}{*}{-.94} & \multirow{2}{*}{.35} \\
\hline & & Bekâr & 69 & 5.42 & 1.02 & & & \\
\hline
\end{tabular}

Tablo 3'te görüldüğü üzere görme yetersizliği olan öğretmenlerin duygusal bağlılık düzeyleri medeni duruma göre evli öğretmenler $(\bar{X}=4.57)$ lehine anlamlı farklılaşmaktadır $(t(152)=2.13, p<.05)$. Öğretmenlerin örgütsel destek düzeyleri cinsiyete göre erkek öğretmenler $(\bar{X}=4.81)$ lehine anlamlı farklılaşmaktadır $(t(152)=-3.57, p<.05)$. Öğretmenlerin örgüt kaynaklı öz saygı düzeyleri cinsiyete göre erkek öğretmenler $(\bar{X}=5.50)$ lehine anlamlı farklılaşmaktadır $(t(152)=2.27, p<.05)$.

\section{Tablo 4}

Öğretmenlerin Örgütsel Destek, Duygusal Bağlllık, Örgüt Kaynaklı Öz Saygl ve Örgütsel Adalet Algılarının Meslekte Çalışma Süresine Göre Anlamlı Bir Farklılık Gösterip Göstermediğine İlişkin ANOVA Sonuçları

\begin{tabular}{|c|c|c|c|c|c|c|}
\hline Ölçek & Değişken & & $n$ & $s d$ & $F$ & $p$ \\
\hline \multirow[t]{2}{*}{ Duygusal Bağl1lık Ölçeği } & & $1-7$ y1l & 69 & \multirow{6}{*}{$3-150$} & \multirow[t]{2}{*}{11.98} & \multirow[t]{2}{*}{.00} \\
\hline & & $8-14$ y1l & 42 & & & \\
\hline \multirow{2}{*}{ Örgütsel Destek Ölçeği } & & 15-21 y1l & 27 & & .11 & .95 \\
\hline & Meslekte çalışma & 22 yıl ve üzeri & 16 & & & \\
\hline \multirow[t]{2}{*}{ Örgütsel Adalet Alg1sı Ölçeği } & süresi & $1-7$ y1l & 69 & & \multirow[t]{2}{*}{.33} & \multirow[t]{2}{*}{.80} \\
\hline & & $8-14$ y1l & 42 & & & \\
\hline Örgüt Kaynaklı Öz Sayg1 Ölçeği & & 15-21 y1l & 27 & & 1.21 & .31 \\
\hline
\end{tabular}

Tablo 4’te görülebileceği gibi öğretmenlerin duygusal bağlılık düzeyleri meslekte çalışma süresi değişkenine göre anlamlı şekilde farklılaşmaktadır $(F(3,150)=11.98, p<.05)$. Post-Hoc testi olan LSD kullanılarak farklılaşmanın kaynağı tespit edilmek istenmiştir. Yapılan analizler sonrasında meslekte çalışma süresi 1-7 yıl olanların ortalamasının $(\bar{X}=3.99)$, meslekte çalışma süresi 8-14 yıl olanların ortalamasından $(\bar{X}=$ 4.45), 15-21 yıl olanların ortalamasından $(\bar{X}=4.58)$ ve 22 ve üzeri yıl olanların ortalamasından $(\bar{X}=5.63)$ daha düşük olduğu görülmüştür. Ayrıca meslekte çalışma süresi 22 ve üzeri yıl olanların ortalamasının $(\bar{X}=5.63), 1-7$ yıl olanların ortalamasından $(\bar{X}=3.99)$; meslekte çalışma süresi 8-14 yıl olanların ortalamasının $(\bar{X}=4.45), 15-21$ y1l olanların ortalamasından $(\bar{X}=4.58)$ olanlardan yüksek olduğu saptanmıştır.

Öğretmenlerin örgütsel destek düzeylerinin $(F(3,150)=.11, p>.05)$, örgütsel adalet algılarının $(F(3$, $150)=.33, p>.05)$, örgüt kaynaklı öz saygılarının $(F(3,150)=1.21, p>.05)$ meslekte çalışma süresi değişkenine göre anlamlı şekilde farklılaşmadığg belirlenmiştir. 


\section{Görme Yetersizliği Olan Öğretmenlerin Örgütsel Adalet Algısı, Duygusal Bağlılık ve Örgüt Kaynaklı Öz Saygı Düzeylerinin Örgütsel Destek Algıları Üzerindeki Etkisi}

Görme yetersizliği olan öğretmenlerin örgütsel adalet algısı, duygusal bağlılık ve örgüt kaynaklı öz sayg1 düzeylerinin örgütsel destek algılarının yordayıcısı olup olmadığını belirlemek için çoklu regresyon analizi yapılmış ve sonuçlar Tablo 5'te verilmiştir.

\section{Tablo 5}

Görme Yetersizliği Olan Öğretmenlerin Örgütsel Adalet Algısı, Duygusal Bağglllık ve Örgüt Kaynaklı Öz Saygı Düzeylerinin Örgütsel Destek Algıları Üzerindeki Etkisine İlişkin Çoklu Regresyon Sonuçları

\begin{tabular}{llcccc}
\hline \multicolumn{1}{c}{ Değişken } & $B$ & Standart hata B & $\beta$ & $t$ & $p$ \\
\hline Örgüt kaynaklı öz sayg1 & .12 & .04 & .12 & 2.90 & .00 \\
Örgütsel adalet algisı & .45 & .06 & .36 & 7.92 & .00 \\
Duygusal örgütsel bağlılık & .59 & .05 & .61 & 13.22 & .00 \\
\hline
\end{tabular}

Not: Bağımlı değişken = Örgütsel destek, $R=.859, R^{2}=.738, F=140.892$.

Tablo 5 'ten görüleceği üzere örgütsel destek ile örgüt kaynaklı öz saygl, örgütsel adalet alglsl ve duygusal bağglllk arasında yüksek düzeyde ve anlamlı bir ilişki bulunmaktadır $\left(R=.859, R^{2}=.738, F=140.892, p=.000\right.$, $p<.05)$. Bu bulgulara göre örgütsel destek algısının \%74'ü örgüt kaynaklı öz saygl, örgütsel adalet algısı ve duygusal bağlllık tarafından açıklanmaktadır. Standardize edilmiş regresyon katsayına göre $(\beta)$ yordayıcı değişkenlerin örgütsel destek üzerindeki göreli önem sırası büyükten küçüğe duygusal bağlllık, örgütsel adalet ve örgüt kaynaklı öz saygı şeklindedir. Regresyon katsayılarının anlamlılığına ilişkin $t$ testi sonuçları incelendiğinde üç bağımsız değişkenin de örgütsel destek algısının anlamlı birer yordayıcısı olduğu görülmüștür. Regresyon analizi sonuçlarına göre, öğretmenlerin örgütsel destek düzeylerini yordayan regresyon denklemi şu şekildedir: Örgütsel Destek $=1.15+(0.12 \times$ Örgüt kaynaklı öz sayg $1+0.45$ x Örgütsel adalet algısını $+0.59 \times$ Duygusal örgütsel bağll lı̆̆ı).

\section{Tartışma}

Bu çalışmada, ilköğretim ve ortaöğretim kurumlarında görevli görme yetersizliği olan öğretmenlerin görüşlerine göre örgütsel adalet, duygusal bağl1lık, örgüt kaynaklı öz saygı ve algılanan örgütsel destek arasındaki ilişkiler incelenmiş̧tir. Araştırmanın örneklemi 2018-2019 eğitim-öğretim yılında ilköğretim ve ortaöğretim kurumlarında görevli 154 görme yetersizliği olan öğretmenden oluşmaktadır. Bulgular, öğretmenlerin örgütsel destek düzeylerinin çok yüksek olduğunu göstermektedir. Alanyazın incelendiğinde hiçbir engeli olmayan öğretmenlere ilişkin yapılan diğer çalışmalarda da örgütsel destek düzeyinin yüksek veya çok yüksek olduğu çalışma bulgularına rastlanmıştır (Akın, 2008; Rhoades \& Eisenberger, 2002). Öğretmenlerin, örgütleri tarafından desteklendiği görülmüştür. Yöneticilerin görme yetersizliği olan öğretmenlerle çalışmaya gönüllüklerinin orta düzeyde olduğu bilinmektedir (Gilbride vd., 2000). Çalışma bulguları bir bütün olarak değerlendirildiğinde okul yöneticilerinin görme yetersizliği olan öğretmenle çalışmaya çok istekli olmamakla beraber, öğretmenlerine destek verdikleri anlaşılmaktadır.

Görme yetersizliği olan öğretmenlerin örgüt kaynaklı öz saygı algılarının yüksek düzeyde olduğu görülmüştür. Görme engeli olmayan öğretmenlere ilişkin alanyazın incelendiğinde benzer sonuçların bulunduğu görülmektedir (Ganster \& Shaubroeck, 1991; Pierce \& Gardner, 2004). Görme yetersizliği olan öğretmenlerin yüksek düzeyde örgüt kaynaklı öz saygıya sahip olmaları, öğretmenlerin okul yöneticileri ve iş arkadaşları tarafından güvenilir ve önemli bulunduklarını düşündüklerini göstermektedir. EGED (2017) görme yetersizliği olan öğretmenlerin \%83'ünün kurum içi yazışmaları sağlıklı olarak takip edemediğini, \%17'sinin idarecileriyle ilişkilerini olumlu olarak değerlendirmediğini ve \%20'sinin ise tamamen ya da kısmen yıldırmaya uğradığını tespit etmişlerdir. Öğretmenlerin orta düzeyde duygusal bağll1ık gösterdikleri saptanmıştır. Gören ve Yengin-Sarpkaya (2014) öğretmenlerde duygusal bağlllık düzeyini orta düzeyde bulmuștur. Görme yetersizliği olan öğretmenlerde benzer sonucun çıkması, engellilik durumunun duygusal bağlanmada farklılık oluşturmadığını göstermektedir. Araş̧ırmada, öğretmenlerin yüksek örgütsel adalet algılarına sahip olduğu saptanmıştır. Cohen ve diğerlerinin (2001) yaptıkları çalışmada öğretmenlerin örgütsel adalet algısının orta veya yüksek olduğu görülmüştür. Görme yetersizliği olan öğretmenlerin okulun imkânlarından diğer öğretmenler ile eşit şekilde faydalandıkları, hak ve sorumlulukların eşit bölüşüldüğünü düşündükleri görülmektedir. Bu düşüncenin, örneklemi oluşturan resmi eğitim kurumlarında çalışan öğretmenlerin hak ve görevlerinin yasalarca korunması gerçeğinden kaynaklandığ1 düşünülmektedir. 
Görme yetersizliği olan öğretmenlerin örgütsel destek düzeyleri cinsiyete göre anlamlı farklılaşmakta ve erkek öğretmenlerin daha çok desteklendiği görülmektedir. Görme yetersizliği olan öğretmenlerle ilgili cinsiyet değişkeninin ele alındığı Polat'ın (2017) çalışmasında da benzer bir bulguya rastlanmaktadır. Öğretmenlerde örgütsel destek algısının cinsiyete göre farklılaşmadığı (Nayır, 2011) veya kadın öğretmenler lehine farklılaştığı çalışmalara da rastlanmaktadır (Kalağan, 2009). Mevcut çalışmada ise görme yetersizliği olan öğretmenlerde erkek öğretmenlerin kadın öğretmenlere göre daha çok örgütsel destek gördüklerini düşünmelerinin birçok nedeni olabileceği düşünülmektedir. Örneğin, kadın öğretmenlerin beklentisinin daha çok olması, daha çok desteğe ihtiyaç duymaları ve/veya yöneticilerin görme yetersizliği olan kadın öğretmenlere karşı olumsuz tutumları olabileceği sayılabilir. Bununla beraber okul yöneticilerinin büyük bir çoğunluğunun erkek olması ve görme yetersizliği olan erkek öğretmenlere karşı empatik davranışlar sergileyebildikleri düşünülmektedir. Öğretmenlerin örgüt kaynaklı öz saygı düzeyleri cinsiyete göre erkek öğretmenler lehine anlamlı şekilde farklılık göstermektedir. Alanyazında örgüt kaynaklı öz saygının cinsiyete göre farklılaşma durumu değişkenlik göstermektedir. Örneğin, Akalın (2006) ve Buruk’un (2006) çalışmalarında cinsiyete göre anlamlı farklılık görülmemişken, Erden (2011) tarafından yapılan çalışmada kadınların lehine anlamlı bir farklılık saptanmıştır. Görme yetersizliği olan öğretmenlerde kadın öğretmenlerin örgüt kaynaklı öz saygı algılarının düşük olmasının kadınlarda görselliğe, fiziksel görünüşe daha çok önem verilmesi ile ilgili olabileceği düşünülmektedir.

Evli öğretmenlerin duygusal bağlılı̆̆ının daha yüksek olduğu görülmüştür. Görme yetersizliği olan öğretmenlerin özelinde evli olmanın duygusal bağlığı artırıcı bir etmen olduğu görülmektedir. Görme yetersizliği olan öğretmenlerin eşleri ile hayata ve mesleklerine bağlılıklarının arttığı sonucuna ulaşılabilir. Bu çalışma bulgusunun aksine Yüner (2018), görme yetersizliği olan öğretmenlerde medeni durumun duygusal bağlılık bakımından farklılık oluşturmadığını bulmuştur. Öğretmenlerin duygusal bağlılık düzeyleri meslekte çalışma süresi değişkenine göre anlamlı şekilde farklılaşmaktadır. Mevcut çalışmaya göre meslekte çalışma süresi artıkça, duygusal bağlılık düzeyleri arttı̆̆ görülmüştür. Bu tespit, Yüner'in (2018) çalışmalarını destekler niteliktedir. Mesleğe ve örgüte verilen emek süresinin artmasının duygusal bağlanmayı artırması anlaşılabilir bir durumdur. Araştırmada öğretmenlerin örgütsel destek algı düzeylerinin meslekte çalışma süresine göre değişmediği görülmüştür. Görme yetersizliği bulunmayan öğretmenler üzerine yapılan çalışmalarda mesleki kıdeme göre örgütsel destek düzeyinin farklılaşmadığı görülmekte (Erkol, 2015; Gül, 2003) ve mevcut araştırma bulgusu ilgili alanyazını desteklemektedir.

Mevcut çalışmanın bulgularına göre örgütsel adalet algısı ile örgüt kaynaklı öz saygı arasında orta düzeyde, pozitif yönlü ve anlamlı bir ilişki vardır. Algılanan örgütsel destek ile örgütsel adalet algısı arasında yüksek düzeyde, pozitif yönlü ve anlamlı, örgüt kaynaklı öz saygı ile yüksek düzeyde, pozitif yönlü ve anlamlı ve duygusal bağlılık ile zayıf düzeyde, pozitif yönlü ve anlamlı ilişki bulunmaktadır. Moorman ve diğerleri (1998) ve Polat (2017) örgütsel destek ile örgütsel adalet arasında anlamlı pozitif yönlü ilişki olduğunu saptamışlardır. Keleş (2015) tarafından yapılan çalışmada da örgütsel adalet algısı ile örgüt kaynaklı öz saygı arasında anlamlı ilişki saptanmıştır.

Mevut çalışma kapsamında yapılan çoklu regresyon analizi sonucunda, örgütsel destek ile örgüt kaynaklı öz sayg1, örgütsel adalet algısı ve duygusal bağlılık arasında yüksek düzeyde ve anlamlı bir ilişki bulunmuştur. Bu bulgulara göre örgütsel destek algıs1; örgüt kaynaklı öz sayg1, örgütsel adalet algısı ve duygusal bağlılık tarafından yüksek düzeyde açıklanmaktadır ve örgüt kaynaklı öz saygı, örgütsel adalet algısı ve duygusal bağlılık, örgütsel destek algısının anlamlı yordayıcılarıdır. Çalışma sonucunda örgütsel adalet algısı ile örgüt kaynaklı öz saygı arasında, örgütsel adalet algıları ile algılanan örgütsel destek arasında ve duygusal bağlılık ile örgüt kaynaklı öz saygı arasında anlamlı ilişki olduğu görülmüştür. Sonuç olarak örgüt kaynaklı öz saygı, örgütsel adalet algısı ve duygusal örgütsel bağlılığın, örgütsel destek algısının anlamlı yordayıcıları olduğu saptanmıştır.

Mevcut çalışma yalnızca görme yetersizliği olan öğretmen görüşleri ile sınırlıdır, dolayısıyla eğitim yöneticileri ve diğer paydaşların görüşleri araştırma kapsamı dışında kalmıştır. Çalışma sınırlılıkları içinde, görme yetersizliği olan öğretmenler başlı̆̆ı altında yapılan çalışmanın, öğretmenin total görme yetersizliğinin olması ve az gören olmasının çalışma bulgularını etkileyebileceği düşünülmektedir. Bir başka unsur da öğretmenin çalıştığı okul, öğrencinin sınıf kademesinin çalışma bulgularında etkisi olabileceğidir.

$\mathrm{Bu}$ çalışmada ortaya konan hususlar doğrultusunda görme yetersizliği olan öğretmenler özelinde örgütsel davranışlara iliş̧̧in farklı değişkenlerin ele alındığı ileri araştırmalar da yapılabilir. Öte yandan çalışmada ortaya çıkan görme yetersizliği olan kadın öğretmenlerde örgütsel destek algısının düşük olmasının sebebinin araştırılması ve bunun sonucunda tespit edilen konularda uygulamacılar tarafından gerekli önlemlerin alınması yerinde olacaktır. Aynı şekilde görme yetersizliği olan erkek öğretmenlerin kadın öğretmenlere göre örgüt kaynaklı öz sayg1, örgütsel bağlılık, örgütsel adalet ve örgütsel destek algılarının daha yüksek olma nedenleri tespit eden yeni araştırmalar planlanması ve farklılıkların olumlu yönde giderilmesi önerilebilir.

\section{Teşekkür}

Araştırmanın ortaya çıkarılması aşamasında destek olan Mitat Enç Görme Engelliler Okulu öğretmenlerine teşekkür ederim. 


\section{Kaynaklar}

Akalın, Ç. (2006). Duygusal örgütsel bağlllık gelişiminde çalı̧̧anların algıladığ örgütsel destek ve ara değiş̧en olarak örgüt temelli öz-saygl [Perceived organizational support in the formation of affective commitment and organization-based self-esteem as an intermediary variable] (Tez Numaras1: 169783) [Yüksek lisans tezi, Hacettepe Üniversitesi]. Yükseköğretim Kurulu Ulusal Tez Merkezi.

Akın, M. (2008). Örgütsel destek, sosyal destek ve iş/aile çatışmalarının yaşam tatmini üzerindeki etkileri [The effects of organizational support, social support and work/family conflicts on life satisfaction]. Erciyes Üniversitesi Sosyal Bilimler Enstitüsü Dergisi, 25(2), 141-171. https://dergipark.org.tr/tr/pub/erusosbilder/issue/23758/253199

Allen, N. J., \& Meyer, J. P. (1990). The measurement and antecedents of affective, continuance and normative commitment to the organization. Journal of Ocupational Psychology, 63(24), 1-18. https://doi.org/10.1111/j.2044-8325.1990.tb00506.x

Aqeel, M., \& Ahmed, S. (2014). Relationship between organizational support and job performance. European Academic Research, 1(11), 4878-4885. http://euacademic.org/UploadArticle/336.pdf

Arshadi, N., \& Hayavi, G. (2013). The effect of perceived organizational support on affective commitment and job performance: Mediating role of OBSE. Social and Behavioral Sciences, 84, 739-743. https://doi.org/10.1016/j.sbspro.2013.06.637

Aselage, J., \& Eisenberger, R. (2003). Perceived organizational support and psychological contracts: A theoretical integration. Journal of Organizational Behavior, 24(5), 491-509. https://doi.org/10.1002/job.211

Başkara, S. V. (2002). Öz saygının bazı değişkenler açısından incelenmesi [Investigation of self-esteem in terms of some variables] (Tez Numarası: 122324) [Yüksek lisans tezi, Ankara Üniversitesi]. Yükseköğretim Kurulu Ulusal Tez Merkezi.

Beheshtifar, M., \& Herat, B. H. (2013). To promote employees commitment via perceived organizational support. International Journal of Academic Research in Business and Social Sciences, 13(1), 306-313. https://www.researchgate.net/profile/MalikehBeheshtifar/publication/281175934_To_Promote_Employ ees_Commitment_via_Perceived_Organizational_Support/links/55d99a5108aeb38e8a87d63a/ToPromote-Employees-Commitment-via-Perceived-Organizational-Support.pdf

Brandsborg, K., Vik, A. K., \& Andersen, K. J. (2001). Hand over hand: A blind teacher of the visually impaired at work with a blind child. British Journal of Visual Impairment, 19(3), 98-105. https://doi.org/10.1177/026461960101900304

Buruk, S. P. (2006). The effect of organization-based self-esteem on the relationship between job characteristics, commitment and perceived performance (Tez Numarası: 207731) [Yüksek lisans tezi, Marmara Üniversitesi]. Yükseköğretim Kurulu Ulusal Tez Merkezi.

Büyüköztürk, Ş. (2007). Sosyal bilimler için veri analizi el kitabı [Data analysis guideline for social sciences]. Pegem A Yayıncilik.

Carson, K. D., Carson, P. P., Lanford, H., \& Roe, C. W. (1997). The effects of organization-based self-esteem on workplace outcomes: An examination of emergency medical technicians. Public Personnel Management, 26(1), 139-155. https://doi.org/10.1177/009102609702600111

Cesur, A., \& Erol, E. (2020). Okul yönetiminde kayırmacılık ve örgütsel adalet arasındaki ilişki: Afyonkarahisar ili örneği [The relationship between favoritism in school management and organizational justice: The sample of Afyonkarahisar]. OPUS Uluslararası Toplum Araştırmaları Dergisi, 15(25), 3467-3496. https://doi.org/10.26466/opus.633508

Chan, S. C., Huang, X., Snape, E., \& Lam, C. K. (2013). The Janus face of paternalistic leaders: Authoritarianism, benevolence, subordinates' organization based self-esteem, and performance. Journal of Organizational Behavior, 34(1), 108-128. https://doi.org/10.1002/job.1797

Cohen-Charash, Y., \& Spector, P. E. (2001). The role of justice in organizations: A meta-analysis. Organizational Behavior and Human Decision Processes, 86(2), 278-321. https://doi.org/10.1006/obhd.2001.2958 
Çetin, M. Ö. (2004). Örgütsel vatandaşlık davranışı [Organizational citizenship behavior]. Nobel Yayın Dağıtım.

Çiğdemoğlu, S. (2006). An examination of peer pressure, self-esteem and personality among $9^{\text {th }}$ year students of different type high schools (Tez Numarası: 318942) [Yüksek lisans tezi, Ankara Üniversitesi]. Yükseköğretim Kurulu Ulusal Tez Merkezi.

Demirtaş H., Özer, N., Demirbilek, N., \& Bal1, O. (2017). Relationship between the perceived principal support, trust in principal and organizational commitment. International Online Journal of Educational Sciences, 9(4), 1075-1092. https://doi.org/10.15345/iojes.2017.04.013

Derinbay, D. (2011). Illkögretim okullarında görev yapan öğretmenlerin alglladıkları örgütsel destek düzeyler [The perceived organizational support level of primary school teachers] (Tez Numarasi: 322445) [Yüksek lisans tezi, Pamukkale Üniversitesi]. Yükseköğretim Kurulu Ulusal Tez Merkezi.

Dünya Sağlık Örgütü [World Health Organization]. (2018). Dünya sağllk örgütü istatistikleri [World health organization https://www.tuseb.gov.tr/enstitu/tacese/yuklemeler/istatistik/9789241565585_eng.pdf

Dyne, L. V., Graham, J. W., \& Dienesch, R. M. (1994). Organizational citizenship behavior: Construct redefinition, measurement, and validation. Academy of Management Journal, 37(4), 765-802. https://doi.org/10.5465/256600

Eğitimde Görme Engelliler Derneği [Association for the Visually Impaired in Education]. (2017). Görme engelli ögretmenlerin görevleri esnasında karşılaştıkları sorunların tespiti raporu [Detection report of problems encountered by visually impaired teachers during their duties]. http://eged.org/gorme-engelli-ogretmen-anketi-sonucu.pdf

Eisenberger, R., Huntington, R., Hutchison, S., \& Sowa, D. (1986). Perceived organizational support. Journal of Applied Psychology, 71(3), 500-507. https://doi.org/10.1037/0021-9010.71.3.500

Erden, N. S. (2011). Mediating effects of organization based self esteem on the relationship between organizational justice and organizational commitment (Tez Numarasi: 291371) [Yüksek lisans tezi, Marmara Üniversitesi]. Yükseköğretim Kurulu Ulusal Tez Merkezi.

Erkol, H. (2015). The investigation of high school teachers' perceived organizational support levels according to their personal traits. Anatolian Journal of Educational Leadership and Instruction, 3(1), 1-17. https://dergipark.org.tr/tr/download/article-file/17504

Ferri, B. A., Keefe, C. A., \& Gregg, N. (2001). Teachers with learning disabilities: A view from both sides of the desk. Journal of Learning Disabilities, 34(1), 22-32. https://doi.org/10.1177/002221940103400103

Ganster, D. C., \& Shaubroeck, J. (1991). Role stress and worker health: An extension of the plasticity hypothesis of self-esteem. Journal of Social Behavior and Personality, 6(7), 349-360. https://psycnet.apa.org/record/1992-03564-001

Gilbride, D. D., Stensrud, R., Ehlers, C., Evans, E., \& Peterson, C. (2000). Employers' attitudes toward hiring persons with disabilities and vocational rehabilitation services. Journal of Rehabilitation, 66(4), 17-23. http://citeseerx.ist.psu.edu/viewdoc/download?doi=10.1.1.999.174\&rep=rep1\&type=pdf

Gören, T., \& Yengin-Sarpkaya, P. (2014). The level of organizational commitment of the teachers in primary schools in Aydin. Journal of Educational Sciences, 40, 69-87. https://www.pegem.net/dosyalar/dokuman/139383-2015072112446-ilkogretim-kurumlarinda.pdf

Greenberg, J. (1990). Looking fair being fair: Managing impressions of organizational justice. Research in Organizational Behavior, 12, 57-111. https://doi.org/10.1007/BF01390438

Gül, H. (2003). The behavioural commitment approach and evaluation. Management and Economics, 10(1), 73 83. https://dergipark.org.tr/tr/pub/yonveek/issue/13678/165505

Güneş, A. M. (2011). İlköğretim okullarında dönüşümcü liderlikle örgütsel adalet arasindaki ilişki (Ağrı ili örneği) [The relationship between transformational leadership and organizational justice (The example of A $\breve{g} r$ )] (Tez Numarasi: 279716) [Yüksek lisans tezi, Gazi Üniversitesi]. Yükseköğretim Kurulu Ulusal Tez Merkezi. 
Gürbüz, S. (2006). A research on identifying the relationships between organizational citizenship behavior and affective commitment. International Journal of Economic and Social Research, 3(1), 48-75. https://dergipark.org.tr/tr/download/article-file/69071

Hazen, M. (2012). Is classroom management possible for disabled teachers, with or without accommodation? [Master's thesis, State University of New York College at Buffalo]. http://digitalcommons.buffalostate.edu/multistudies theses/4

Hoy, W. K., \& Tarter, C. J. (2004). Organizational justice in schools: No justice without trust. International Journal of Educational Management, 18(4), 250-259. https://doi.org/10.1108/09513540410538831

Hui, C., \& Lee, C. (2000). Moderating effects of organization-based self-esteem on organizational uncertainty: Employee response relationships. Journal of Management, 26(2), 215-232. https://doi.org/10.1177/014920630002600203

İyigün, N. Ö. (2012). Örgütsel adalet: Kuramsal bir yaklaşım [Organizational justice: A theoritical approach]. İstanbul Ticaret Üniversitesi Sosyal Bilimler Dergisi, 11(21), 49-64. https://ders.es/orgutsel_davranis/orgutsel_adalet.pdf

Jeon, J. H. (2009). The impact of organizational justice and job security on organizational commitment exploring the mediating effect of trust in top management [Doctoral dissertation, The University of Minnesota]. https://conservancy.umn.edu/handle/11299/54242

Karasar, N. (1994). Araştırmada rapor hazırlama [Preparing report in research]. 3A Araştırma Eğitim Danışmanlık.

Kalağan, G. (2009). Araştırma görevlilerinin örgütsel destek algıları ile örgütsel sinizm tutumları arasındaki ilişki [The relationship between researh assistants' perceived organizational support and organizational cynicism] (Tez Numarası: 250571) [Yüksek lisans tezi, Akdeniz Üniversitesi]. Yükseköğretim Kurulu Ulusal Tez Merkezi.

Kaneshiro, P. (2008). Analyzing the organizational justice, trust and commitmentinal public organization. [Unpublished doctoral dissertation]. Northcentral University.

Kaplan, M., \& Öğ̈̈t, A. (2012). The analysis of relationship between perceived organizational support and organizational commitment: A case of study in hotel businesses. Süleyman Demirel University The Journal of Faculty of Economics and Administrative Sciences, 17(1), 387-401. https://dergipark.org.tr/tr/download/article-file/194439

Keleş, E. (2015). Yaşam doyumunu yordayan örgütsel değişkenler: Örgüt temelli özsaygının düzenleyici rolü [The organizational predictors of life satisfaction: The mediating role of organization-based self-esteem] (Tez Numarasi: 407588) [Yüksek lisans tezi, Mersin Üniversitesi]. Yükseköğretim Kurulu Ulusal Tez Merkezi.

Korman, A. K. (1970). Toward an hypothesis of work behavior. Journal of Applied Psychology, 54(1), 31-41 https://doi.org/10.1037/h0028656

Köse, A. (2016). The relationship between work engagement behavior and perceived organizational support and

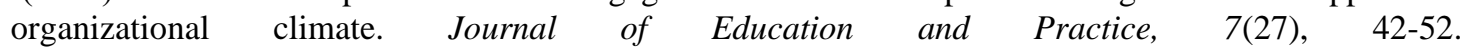
https://files.eric.ed.gov/fulltext/EJ1115916.pdf

Kuo, B. C. H. (2013). Collectivism and coping: Current theories, evidence, and measurements of collective coping. International Journal of Psychology, 48(3), 374-388. https://doi.org/10.1080/00207594.2011.640681

Meyer, J. P., \& Allen N. J. (1991). A three-component conceptualization of organizational commitment. Human Resource Management Review, 1(1), 64-89. https://doi.org/10.1016/1053-4822(91)90011-Z

Meyer, J. P., Allen, N. J., \& Smith, C. A. (1993). Commitment to organizations and occupations: Extension and test of a three-component conceptualization. Journal of Applied Psychology, 78(4), 538-551. https://doi.org/10.1037/0021-9010.78.4.538 
Moorman, R. H., Blakey, G. L., \& Niehoff, B. P. (1998). Does perceived organizational support mediate the relationship between procedural justice and organizational citizenship behavior. The Academy of Management Journal, 41(3), 351- 357. https://doi.org/10.5465/256913

Mowday, R. T., Porter, L. W., \& Steers, R. M. (1982). Employee-organization linkages. Academic Pres.

Nayır, F. (2011). İlköğretim okulu yöneticilerinin öğretmenlere sağlanan örgütsel desteğe ilişkin görüşleri, ögretmenlerin örgütsel destek algısı ve örgütsel bağlllikla ilişsisi [Opinions of primary schools principals about organizational support provided for teachers, relationship between perception of organizational support and level organizational commitment of teachers working at primary schools] (Tez Numaras1: 302890) [Doktora tezi, Ankara Üniversitesi]. Yükseköğretim Kurulu Ulusal Tez Merkezi.

Nayır, F. (2012). The relationship between perceived organizational support and teachers' organizational commitment. Eurasian Journal of Educational Research, 48(1), 97-116. https://files.eric.ed.gov/fulltext/EJ1057713.pdf

Önderoğlu, S. (2010). Örgütsel adalet algısı, iş aile çatışması ve algılanan örgütsel destek arasındaki bağlantılar [The relationships between perceptions of organizational justice, work family conflict and perceived organizational support] (Tez Numarası: 273306) [Yüksek lisans tezi, Ankara Üniversitesi]. Yükseköğretim Kurulu Ulusal Tez Merkezi.

Payne, H. J. (2007). The role of organization-based self-esteem in employee dissent expression. Communication Research Reports, 24(3), 235-240. https://doi.org/10.1080/08824090701446609

Pierce, J. L., \& Gardner, D. G. (2004). Self-esteem within the work and organizational context: A review of the organization-based self-esteem literature. Journal of Management, 30(5), 591-622. https://doi.org/10.1016/j.jm.2003.10.001

Pierce, J. L., Gardner, D. G., Cummings, L. L., \& Dunham, R. B. (1989). Organization-based self-esteem: Construct definition, measurement, and validation. Academy of Management Journal, 32(3), 622-648. https://doi.org/10.2307/256437

Polat, Ş. (2017). Görme yetersizliği olan ve olmayan öğretmenlerin örgütsel destek ve örgütsel adalet algıları [Organizational support and organizational justice perceptions of teachers with and without visual 1mpairments]. Ankara Üniversitesi Eğitim Bilimleri Fakültesi Özel Eğitim Dergisi, 19(3), 511-530. https://doi.org/10.21565/ozelegitimdergisi.357697

Restad, R. O. (1972). A survey of attitudes held by school administrators toward blind teacher applicants [Master's thesis, Minnesota State University]. https://eric.ed.gov/?id=ED077877

Revathi, M., \& Naomi, G. V. (2016). Administrators attitude towards visually impaired teachers. International Education and Research Journal, 2(4), 94-95. http://ierj.in/journal/index.php/ierj/article/view/239/223

Rhoades, L., \& Eisenberger, R. (2002). Perceived organizational support: A review of the literature. Journal of Applied Psychology, 87(4), 698-714. https://doi.org/10.1037//0021-9010.87.4.698

Sholihin, M., \& Pike, R. (2010). Organizational commitment in the police service: Exploring the effects of performance measures, procedural justice and interpersonal trust. Financial Accountability and Management, 26(4), 392-421. https://doi.org/10.1111/j.1468-0408.2010.00507.x

Songür, N., Basım, H. N., \& Şeşen, H. (2008). Örgütsel vatandaşlık davranışında adalet algısının öncüllük rolü [The antecedent role of justice perception on organization al citizenship behavior]. Amme İdaresi Dergisi, 41(4), 79-100. https://www.researchgate.net/publication/303860233

Türkiye Cumhuriyeti Devlet Personel Başkanlı̆̆ı [State Personnel Presidency]. (2018). Engelli personel istatistikleri 2018 kitapçı̆̆l. $\quad$ http://www.dpb.gov.tr/tr-tr/istatistikler/engelli-personel-ve-omss$\underline{\text { istatistikleri }}$

Türk Dil Kurumu [Turkish Language Association]. (t.y.). Güncel Türkçe Sözlük. https://sozluk.gov.tr/

Valle, J., Solis, S., Volpitta, D., \& Connor, D. (2004). The disability closet: Teachers with learning disabilities evaluate the risks and benefits of "coming out". Equity \& Excellence in Education, 37(1), 4-17. https://doi.org/10.1080/10665680490422070 
Vogel, S., Murray, C., Wren, C., \& Adelman, P. (2007). An exploratory analysis of employment related experiences of educators with learning disabilities. Educational Considerations, 37(2), 15-20. https://doi.org/10.4148/0146-9282.1206

Yazıcıŏlu, Y., \& Erdoğan, S. (2004). SPSS uygulamalı bilimsel araştırma yöntemleri [SPSS applied scientific research methods]. Detay Yayınc1lik.

Yüner, B. (2018). Örgüt temelli öz saygı ve örgütsel duygusal bağlllığa ilişkin öğretmen görüşleri [Teachers’ views on organization based self esteem and emotional organizational commitment]. Ankara Üniversitesi $\begin{array}{llllll}\text { Eğitim Bilimleri Fakültesi Özel Eğitim Dergisi, } & 19(4), & \text { 777-799. }\end{array}$ https://doi.org/10.21565/ozelegitimdergisi.396246 


\section{Ankara University Faculty of Educational Sciences Journal of Special Education}

2022, 23(2), 345-364

\title{
Investigation of the Relationships between Affective Commitment, Organization-based Self-esteem, Organizational Justice and Organizational Support
}

\author{
Şule Polat iD1
}

\begin{abstract}
Introduction: Organizational behaviors, which have significant effects on employees, are more sensitive in terms of teachers with visual impairment. In this study, we aimed to examine the relationship between organizational justice, affective commitment, organization-based self-esteem and perceived organizational support, according to the views of visually impaired teachers working in elementary and secondary schools.
\end{abstract}

Method: The sample of the study consisted of 154 visually impaired teachers working in primary and secondary education institutions in the 2018-2019 academic years. In this study, relational screening method was used and the data were analyzed by quantitative techniques. Research data were gathered with the "Organizational Support Scale", "Organizational Justice Perception Scale", "Organization-based Self-esteem Scale" and "Affective Organizational Commitment Scale". In data analysis, frequency, arithmetic mean, percent and standard deviation and parametric testes were used.

Findings: According to the findings, participants' organizational support perceptions differed in favor of male teachers and married teachers, and participants' organization-based self-esteem perception levels also differed in favor of male teachers. There were significant relationships between organizational justice perception and organization-based self-esteem, between perceived organizational support and organizational justice perception, and between organization-based self-esteem and affective organizational commitment. As a conclusion, it was found that organization-based self-esteem, organizational justice perception, and affective organizational commitment were significant predictors of perceived organizational support.

Discussion: It has been observed that the affective organizational commitment of visually impaired teachers working in primary and secondary education institutions to their schools is at a moderate level. Similar results were obtained in studies conducted with teachers without visual impairment, shows that visual impairment does not affect affective organizational commitment in teachers. When the literature is examined, it is understood that although school administrators are not very willing to work with teachers with visual impairment, they support their teachers. In this study, it is seen once again that organizational support and organization-based self-esteem increase in case of organizational justice in schools.

Keywords: Teacher, visual impairment, organizational justice, organizational support, affective commitment, organizational behavior.

To cite: Polat, Ş. (2022). Investigation of the relationship between affective commitment, organization-based selfesteem, organizational justice and organizational support. Ankara University Faculty of Educational Sciences Journal of Special Education, 23(2), 345-364. https://doi.org/10.21565/ozelegitimdergisi.771552

${ }^{1}$ Dr., Ministry of National Education, E-mail: sule.polat@yahoo.com, https://orcid.org/0000-0001-5469-5758 


\section{Introduction}

When the interaction between the attitudes of organizations towards their employees and the attitudes of employees towards their organizations is examined; it is seen that perceived organizational support, perception of organizational justice, affective commitment and organization-based self-esteem are the main variables studied in both national and international literature. (Derinbay, 2011; Köse, 2016; Rhoades \& Eisenberger, 2002). These variables are handled individually or dually. Eisenberger et al. (1986) define organizational support as the perception related to organizations' giving importance to the value and happiness of their employees and carrying out the actions and policies which affect their employees in a voluntary manner. It is known that employers carry the tendency to help their organizations acquire humane characteristics (Eisenberger et al., 1986). Employees interpret the treatment they encounter in their organizations through the behaviors of administrators (Aselage \& Eisenberger, 2003). Beheshtifar and Herat (2013) define the perception of organizational support as "managers' awareness of their employees' contributions to the organization and concerns about the well-being of the employees, according to the perception of the employees". These perceptions are determined by the acceptance of the employees by the organizations, their sincerity and the material and moral awards that the employees receive as a result of their efforts in the workplace.

Rhoades and Eisenberger (2002), stated that there is a high level of relationship between organizational justice and organizational support in their study examining 70 studies, In another study, it was determined that the principal's support and trust increase teachers' organizational commitment (Demirtaş et al., 2017). Employees' organizational commitment provides higher work performance to employees (Arshadi \& Hayavi, 2013). Aqeel and Ahmed (2014) determined that higher organizational commitment of employee resulted higher job performance, and "voluntary" responsibility of employee for achieving organizational goals. Eisenberger et al. (1986) defined organizational commitment as a social exchange between employers and employees. They stated that the commitment of organizations to their employees contributes to the commitment of employees to their organizations.

The concept of organizational commitment has been defined by Mowday et al. (1982) as the identification power of an individual's identity with the organization. In addition, three types of organizational commitment are mentioned as continuance commitment, normative commitment and emotional commitment (Meyer \& Allen, 1991). Continuance commitment seems to be related to the awareness of the cost of leaving the organization. Employees, whose relationship with the organization is based on continuance commitment, are thought to remain in the organization due to their material and job satisfaction needs (Meyer \& Allen, 1991). In normative commitment, the employees believe that working in their organization is right. Relationships between the employee and the organization can also develop in line with psychological contracts.

Affective commitment refers to emotional ties of employees with the organization and their identification with it. In this commitment type, employees can identify themselves with their organizations and give great importance to their organizations (Allen \& Meyer, 1990). According to Gül (2003), affective commitment expresses employees' acceptance of organizational values and objectives and their spending a superhuman effort for the benefit of their organizations. The organizations for employees who have affective commitment towards their organizations carry great importance and employees wish to remain in their organizations. Gürbüz (2006) summarized affective commitment as the belief in organizational objectives and values and strong acceptance of these objectives and values, willing to spend more effort for the benefit of the organization and the existence of a strong desire to continue organizational membership.

Affective commitment factors are listed as difficulty of work, clarity of roles, clarity of objectives, difficulty of objectives, openness of the administration towards suggestions, friend loyalty, organizational addiction, equality, personal importance, feedback and participation (Allen \& Meyer, 1990). In this context, hard and exciting work, clear expectations of the organization, knowing the purpose of the organization by employees, relationships, equal treatment towards employees, giving value to employees, giving feedback to employees about their work are some of the factors that increase affective commitment. The high number of employees with high emotional involvement brings less absenteeism in the workplace and higher work motivation. Increasing the number of employees with high affective commitment leads to less absence in the work environment and a higher work motivation (Çetin, 2004).

Self-esteem refers to the respect of individuals towards themselves, thus liking, considering and accepting their own selves as important (Turkish Language Association, 2018). Individuals with high self-esteem are more active in society and better express themselves; whereas those with low self-esteem tend to see themselves as 
worthless, weak and helpless, and have a high level of anxiety (Çetin, 2004; Çiğdemoğlu, 2006). Self-esteem is not static and can change in accordance with the conditions. The change in self-esteem causes changes in individual's reactions and behaviors towards events as well (Başkara, 2002). Korman (1970) is considered to be the first person to bring up the concept of self-esteem in employees. As the researchers who first used the concept, Pierce et al. (1989) defined organizational self-esteem as the employee's level of belief that their needs are satisfied and their roles are met within the organization. Hui and Lee (2000) concluded that employees with low level of organization-based self-esteem also have low organizational commitment and that these people have high job absenteeism. Carson et al. (1997) found that organization-based self-esteem increases the organizational commitment of employees. In addition, some studies have shown that employees with high organization-based self-esteem have high job motivation, are open more to cooperation, have high job performance, and are devoted to their organizations (Dyne et al., 1994; Kuo, 2013).

Organization-based self-esteem can be defined as "the feelings of worth or value employees feel within their workplace" (Payne, 2007, p. 237). Organization-based self-esteem reflects employees' perceptions about their importance, meaningfulness, effectiveness, competence and value within their organizations (Chan et al., 2013). Pierce and Gardner (2004) stated that employees with low organization-based self-esteem decreased their productivity and had the intention to leave the work, while the effectiveness and efficiency of employees increased who realized that they were an important part of the organization.

Greenberg (1990) used the concept of organizational justice for the first time in terms of the perception of employees regarding fair distribution of gains, fair treatment of managers to their employees, and fairness in organizational regulations, practices and decisions. Greenberg (1990) claimed that many organizational behaviors could be explained through organizational justice. According to Moorman et al. (1998); organizational justice defines the justice that is directly related to the workplace and is a concept related to the situations in which employees think that they are treated fairly and how this situation affects other issues related to the work. Kaneshiro (2008) expresses the perception of organizational justice as the employees' perception of managerial evaluation and decision processes with variables such as work time, authority, duty, work environment, punishment, reward, and wage. In case organizational justice is established within an organization, employees regard themselves as valuable within the organization and thus organizational effectiveness and efficiency increases (İyigün, 2012). Jeon (2009) and Sholihin and Pike (2010) determined that organizational justice increases organizational trust in their studies; while Gürbüz (2006) and Songür et al. (2008) found that organizational justice increases the behavior of organizational citizenship.

Increasing the efficiency and motivation of employees in organizations is indisputable for the success of the organization. Teachers are key employees in educational organizations. Therefore it is important to determine the factors that satisfy teachers and make them more productive for the success of educational organizations. In this context, impaired teachers should be more visible in school environments and be accepted by students, other teachers and administrators. There are 253 million people all over the world who have visual disabilities, 36 million whom are blind (World Health Organization, 2018). It is known that individuals with visual disabilities are the members of the occupation group since the 1980-1990's (Revathi \& Naomi, 2016). In studies which examine the attitudes of administrators towards disabled people, it has been determined that the difficulties faced by visually impaired employees were found to be higher than those in other disability groups (Gilbride et al., 2000). In addition, it is known that the attitudes of administrators towards teachers with visual disabilities are of medium level positive (Restad, 1972). A similar finding is the moderate desire of administrators to work with visually impaired teachers (Revathi \& Naomi, 2016). On the other hand, there are studies that show that teachers with disabilities, who work in schools for the disabled, give more trust to parents and that the low expectations of disabled teachers make parents comfortable (Ferri et al., 2001). On the other hand, there are some study findings determine that disabled teachers working in schools for the disabled give more confidence to parents and that the low expectations of disabled teachers make parents comfortable (Ferri et al., 2001). Teachers with disabilities state that they spend more effort than their power in order to gain the positive view of their colleagues and administrators (Hazen, 2012). Teachers with disabilities state that they spend more effort than their power in order to gain the positive view of their colleagues and administrators (Hazen, 2012). In the study of the Association for the Visually Impaired in Education (AVIE, 2017), it was determined that the communication of visually impaired teachers were mostly in cooperation with colleagues, students, parents and auxiliary staff. In the same study, it was observed that nearly $20 \%$ of visually impaired teachers were exposed to mobbing and $17 \%$ of them had not positive relations with their administrators. Brandsborg et al. (2001) argue that the visually impaired teacher teaches the information that enables the visually impaired student to lead a comfortable life and will be a more reliable role model because 
they have a common identity. In their study they determined that teachers with visual impairment were disadvantaged in situations requiring physical activity, but while both the teacher and the student were visually impaired, they communicated more closely.

In the $27^{\text {th }}$ Article of the Convention on the Rights of Persons with Disabilities discrimination based on disability is prohibited in all issues relating to recruitment and employment. Discrimination is also prohibited in accordance with the Equality Principle of the Constitution, the Disabled Law No. 5378 and $122^{\text {nd }}$ Article of the Penal Code. On the other hand, there are implementations within the scope of positive discrimination such as the obligation of organizations to employ people with visual disabilities, allocating additional time in central examinations and holding examinations for the employment of disabled civil servants as well. According to the Turkish statistics, there are 53017 disabled civil servants and 10450 civil servants with visual disabilities employed (State Personnel Presidency, 2018). There are 3925 disabled teachers employed by the Ministry of Education and it is estimated that there are around 1000 teachers with visual disabilities (AVIE, 2017). Thus, teachers with visual disabilities among the disabled employees have an important place (17-20\%). In this study, the relationships between organizational justice perception, affective commitment, organization-based self-esteem and organizational support were analyzed according to the views of visually impaired teachers. Literature on organizational behavior shows that although there are a limited number of studies on teachers who have visual disabilities, there are no studies on the variables which are dealt with in this study. It is considered that this study on the views of teachers who have visual disabilities will contribute to the literature and will fill the gap in the literature even if partly. Within the scope of this aim, the answers to the following questions were sought.

1. What are the teachers' views on organizational support, affective commitment, organization-based selfesteem and organizational justice perception?

2. Is there a significant relationship between organizational support, affective commitment, organizationbased self-esteem and organizational justice perception according to teachers' opinions?

3. Do teachers' of views on organizational support, affective commitment, organization-based self-esteem and organizational justice perception differ significantly according to gender, marital status and professional seniority?

4. Are organizational justice perception, affective commitment and organization-based self-esteem a meaningful predictor of organizational support?

\section{Method}

In this study, relational screening method was used and the data were analyzed by quantitative techniques. Karasar (1994), relational screening model was used to determine the presence and the degree of the covariance between the correlation of more than two variables. Research data were gathered with the "Organizational Support Scale", "Organizational Justice Perception Scale", "Organization-based Self-esteem Scale" and "Affective Organizational Commitment Scale".

\section{Study Group}

The population of the study consisted a total of 3925 visually impaired teachers employed in public primary and secondary schools in all cities of Turkey in 2018-2019 academic year. The participants were selected randomly. The scale was applied to 154 participants who were reached.

\section{Data Collection Tools}

\section{Affective Commitment Scale}

For the purpose of determining the level of affective commitment perception, the 'Affective Commitment Scale' developed by Meyer et al. (1993) and adapted in Turkish by Akalın (2006) was used. The Cronbach alpha value of the Turkish version of the scale was calculated as .80 (Akalın, 2006). In the current study, the Cronbach alpha reliability coefficient was calculated as .70. It was determined that the scale explains $45 \%$ of the total variance.

\section{Organizational Support Scale}

The scale of 36 items developed by Eisenberger et al. (1986) and adapted to Turkish by Akalın (2006) was used. The Cronbach alpha value of the Turkish version of the scale was calculated as .87 (Akalın, 2006). In 
the current study, the Cronbach alpha reliability coefficient was calculated as .70. It was determined that the scale explains $55 \%$ of the total variance.

\section{Organizational Justice Scale}

The scale developed by Hoy and Tarter (2004) and adapted to Turkish by Güneş (2011) was used. The Cronbach alpha value of the Turkish version of the scale was calculated as .91 by Güneş (2011). In the current study, the Cronbach alpha reliability coefficient was calculated as .94. It was determined that the scale explains $\%$ 75 of the total variance.

\section{Organization-Based Self-Esteem Scale}

The scale developed by Pierce et al. (1989) and adapted to Turkish by Akalın (2006) was used. The Cronbach alpha value of the Turkish version of the scale was calculated as .93 by Akalin (2006). In the current study, the Cronbach alpha reliability coefficient was calculated as .83. It was determined that the scale explains $70 \%$ of the total variance.

\section{Procedures and Data Analysis}

The analysis of the data was conducted through Confirmatory Factor Analysis (CFA), Pearson Correlation and multiple regression analysis along with descriptive statistics. According to the Normalcy Test related to the scales, the kurtosis and skewness values of the total score average of the items were analyzed in the .05 significance level. Based on these results, it was found appropriate to use parametric tests. In data analysis, frequency, arithmetic mean, percent and standard deviation and parametric testes were used.

\section{Results}

According to the findings, teachers' organizational justice perceptions were high, the level of organization-based self-esteem was high, the level of organizational support perception was very high, and the level of affective commitment perception was moderate. Affective commitment levels of teachers differed significantly in favor of married. Organizational support perception levels and organization-based self-esteem levels of teachers differed significantly in favor of male teachers. Affective commitment levels of teachers differed significantly according to the variable of professional seniority. It was determined that teachers' organizational support levels, organizational justice perception levels, and organization-based self-esteem levels did not differ significantly according to professional seniority.

The results of the study showed that there were significant relationships between organizational justice perception and organization-based self-esteem, between perceived organizational support and organizational justice perception, and between organization-based self-esteem and affective organizational commitment. As a conclusion, it was found that organization-based self-esteem, organizational justice perception, and affective organizational commitment were significant predictors of perceived organizational support. According to these findings, $74 \%$ of organizational support perception was explained by organization-based self-esteem, organizational justice perception and affective commitment.

\section{Discussion}

The findings showed that the level of participants' organizational support perception was very high. When the literature had been reviewed, it was seen that the level organizational support perception was either high or very high in the findings of the other studies on teachers without any disabilities (Ak1n, 2008; Rhoades \& Eisenberger, 2002). These findings showed that teachers had the perception that they are supported by their organizations. When evaluated with the finding that administrators were moderately willing to work with visually impaired teachers (Gilbride et al., 2000), this situation indicates that school administrators support visually impaired teachers, although they are not very willing to work with them.

In this study, it was seen that the level of visually impaired teachers' organizational support perception differed in favor of male teachers. The reasons for this may be the higher expectation of female teachers, their need for more support, and the negative attitudes of administrators towards visual impaired female teachers. However, the majority of school administrators are male and it is thought that they can exhibit more empathic behavior towards visually impaired male teachers.

The finding of this study regarding the lack of differentiation in organizational support perception levels according to professional seniority is consistent with the other studies (Erkol, 2015; Gül, 2003) conducted on non- 
disabled teachers. Similarly, the finding regarding the high level of organization-based self-esteem is consistent with the other studies (Ganster \& Shaubroeck, 1991; Pierce \& Gardner, 2004) conducted on non-disabled teachers. The fact that visually impaired teachers have a high level of organization-based self-esteem shows that they are regarded as reliable and important by school administrators and colleagues. AVIE (2017) determined that $83 \%$ of the visually impaired teachers could not follow the internal correspondence properly, $17 \%$ did not evaluate their relations with their administrators positively, and $20 \%$ were completely or partially being exposed to mobbing.

In this study, the organization-based self-esteem levels of teachers differed significantly according to gender in favor of male teachers. Findings regarding the differentiation of organization-based self-esteem according to gender are not consistent in the literature. For instance, while the studies of Akalın (2006) and Buruk (2006) did not determine a significant difference in terms of gender, a significant difference was determined in favor of females in the study conducted by Erden (2011). It is thought that the low level of organization-based self-esteem perceptions of visually impaired female teachers may be related to the fact that women attach more importance to visuality and physical appearance.

In the study, it was determined that visually impaired teachers had a moderate level of affective organizational commitment. Gören and Yengin (2014) also found the level of affective commitment of primary school teachers to be moderate. Similar results in visually impaired teachers suggest that disability does not make a difference in affective attachment. Also it was observed that the professional seniority, the higher the emotional commitment levels. This determination supports the studies of Yüner (2018). It is understandable that the increase in the labor time given to the profession and the organization increases the emotional attachment. According to the current study, it was observed that as professional seniority increases, the level of affective organization commitment also increases. This determination supports the study of Yüner (2018). Increase of the level of affective organization commitment due to the professional seniority is an understandable fact.

In the study, it was determined that visually impaired teachers had high organizational justice perceptions. Cohen et al. (2001), found teachers' organizational justice perception level as moderate or high. It is observed that visually impaired teachers benefit from the school's facilities equally with other teachers, and they think that their rights and responsibilities are equally distributed. It is thought that this opinion of the visually impaired teachers is due to the fact that their rights and duties are protected by law.

There is a medium level, positive and significant relationship between the perception of organizational justice and organization-based self-esteem. There is a high level, positive and meaningful relationship with perceived organizational support and the perception of organizational justice; a high level, positive, meaningful relationship with organization-based self-esteem and a weak, positive and significant relationship with affective commitment. Moormanet et al. (1998) determined that there is a significant positive relationship between organizational support and organizational justice. In the study by Keleş (2015), it was determined that there is a significant relationship between the perception of organizational justice and organization-based self-esteem. As a result of the multiple regression analysis in current study, a significant relationship was determined between organizational support and organization-based self-esteem and a high level and statistically significant relationship between the perception of organizational justice and affective commitment.

\section{Acknowledgment}

I would like to thank the teachers of Mitat Enç School for Visually Impaired who supported the preparation of the research. 